\title{
Grazing impact on the cyanobacterium Microcystis aeruginosa by the heterotrophic flagellate Collodictyon triciliatum in an experimental pond
}

\section{$\operatorname{AUTHOR}(\mathrm{S})$ :}

Kobayashi, Yuki; Hodoki, Yoshikuni; Ohbayashi, Kako; Okuda, Noboru; Nakano, Shin-ichi

\section{CITATION:}

Kobayashi, Yuki ... [et al]. Grazing impact on the cyanobacterium Microcystis aeruginosa by the heterotrophic flagellate Collodictyon triciliatum in an experimental pond. Limnology 2013, 14(1): 43-49

\section{ISSUE DATE:}

2013-01

URL:

http://hdl.handle.net/2433/169749

\section{RIGHT:}

The final publication is available at www.springerlink.com; This is not the published version. Please cite only the published version.; この論文 は出版社版でありません。引用の際には出版社版をご確認ご利用くだ さい。 
1 Title

2 Grazing impact on the cyanobacterium Microcystis aeruginosa by the

3 heterotrophic flagellate Collodictyon triciliatum in an experimental pond

4 Yuki Kobayashi, Yoshikuni Hodoki, Kako Ohbayashi, Noboru Okuda, Shin-ichi

5 Nakano*

6

7 Center for Ecological Research, Kyoto University, 2-509-3 Hirano, Otsu, Shiga

8 520-2113, Japan

9

10

$11 *$ Correspondence:

12 Center for Ecological Research, Kyoto University, 2-509-3 Hirano, Otsu, Shiga

13 520-2113, Japan

14 Tel: +81-77-549-8239,

15 Fax: +81-77-549-8201,

16 *Email: nakano@ecology.kyoto-u.ac.jp

17 


\section{Abstract}

We estimated the grazing impact of the heterotrophic flagellate Collodictyon

triciliatum on the harmful, bloom-forming cyanobacterium Microcystis aeruginosa in an experimental pond during Microcystis bloom from summer to winter in 2010. For

5 these experiments, we calculated the grazing rates from the $C$. triciliatum digestion rate

6 and food vacuole content. During the study period, M. aeruginosa exhibited one

7 blooming event with a maximum density of $1.1 \times 10^{5}$ cells $\mathrm{ml}^{-1}$. The cell density of $C$.

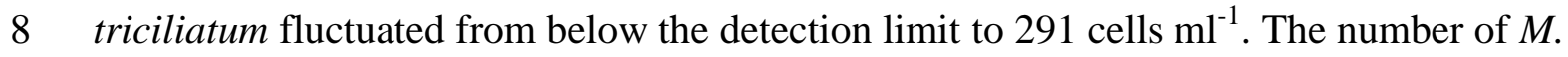

9 aeruginosa cells ingested by $C$. triciliatum food vacuoles ranged between 0.4 and 10.8

10 cells flagellate ${ }^{-1}$, and the digestion rate of $C$. triciliatum at $25^{\circ} \mathrm{C}$ was $0.73 \%$ cell contents

$11 \mathrm{~min}^{-1}$. The grazing rate of $C$. triciliatum on $M$. aeruginosa prey was $0.2-6.9$ cells

12 flagellate $\mathrm{h}^{-1}$, and its grazing impact was $0.0-25.3 \%$ standing stock day ${ }^{-1}$. The

13 functional response of $C$. triciliatum to $M$. aeruginosa prey followed the

14 Michaelis-Menten model of significance $\left(r^{2}=0.873, p<0.001\right)$ in our experimental

15 systems in which the prey concentration varied from $1.0 \times 10^{4}$ to $2.1 \times 10^{6}$ cells ml $^{-1}$. The

16 maximum grazing rate was 6.2 prey cells grazer $^{-1} \mathrm{~h}^{-1}$, and the half-saturation constant

17 was $1.2 \times 10^{5}$ cells $\mathrm{ml}^{-1}$. We present evidence that $C$. triciliatum grazing explained the

18 remarkable decrease in $M$. aeruginosa cell density in the pond. The present study is the 
1 first demonstration of the high potential of protistan grazing on $M$. aeruginosa to reduce

2 cyanobacterial blooms.

3

4 Key words: Microcystis aeruginosa, Collodictyon triciliatum, Functional response,

$5 \quad$ Ingestion, Grazing impact

6

7 
1

malhamensis (Zhang et al. 1996), Poterioochromonas sp. (Zhang et al. 2009),

13 Collodictyon triciliatum (Nishibe et al. 2002), Diphylleia rotans (Kim et al. 2006),

14 Ochromonas danica (Cole and Wynne 1974), and Ochromonas sp. (Burkert et al. 2001;

15 Yang et al. 2008; Baek et al. 2009; Van Donk et al. 2009; Yang et al. 2009; Wilken et al.

16 2010). These flagellate species retain active growth, even while feeding on toxic $M$.

17 aeruginosa. Nishibe et al. (2002) determined the specific grazing rate of the large

18 flagellate $C$. triciliatum on $M$. aeruginosa using a method proposed by Dolan and Šimek 
1 (1998), and applied the rate to estimate the in situ grazing pressure on a cyanobacterium

2 population in a eutrophic pond. One would expect a high impact because of the large

3 cell size (30-50 $\mu \mathrm{m}$ in length) of the flagellate, but it in fact had a low impact on the

4 cyanobacterium. Beyond that study, ecophysiological reports on C. triciliatum remain

5 limited.

6

In the present study, we determined the specific grazing rate of $C$. triciliatum

7 on $M$. aeruginosa based on the digestion rate of $M$. aeruginosa cells in the food

8 vacuoles of $C$. triciliatum (Dolan and Šimek 1998). In addition, we examined the

9 functional response of $C$. triciliatum to $M$. aeruginosa. Using these results, we

10 estimated the grazing impact by the flagellate on an $M$. aeruginosa bloom that occurred

11 in an outdoor experimental pond.

\section{Materials and Methods}

\section{Monitoring biological abundance}

We monitored a Microcystis bloom and $C$. triciliatum abundance in a

16 meso-scale experimental pond $(10 \mathrm{~m} \times 10 \mathrm{~m}$ width; maximum depth, $1.7 \mathrm{~m}$; water

17 volume, ca. $70 \mathrm{~m}^{3}$ ) located at the Center for Ecological Research, Kyoto University,

18 Japan $\left(34^{\circ} 58^{\prime} 2.24^{\prime \prime} \mathrm{N}, 135^{\circ} 57^{\prime} 38.93^{\prime \prime} \mathrm{E}\right)$. We artificially induced the bloom, which is 
1 described in detail in Hodoki et al. (2011). Water samples were collected from the pond

2 surface with a 5L plastic bucket, and poured into three sterilized polycarbonate bottles.

3 Samples were taken at the same time of day (10:00 to 10:30 h) about once weekly from

41 July 2010 to 28 December 2010, and the water temperature was measured

5 simultaneously with a bar thermometer. To measure the chlorophyll $a$ (chl $a$ )

6 concentration, we filtered a measured portion of each water sample through a GF/F

7 filter to retain seston, and stored the samples in a freezer at $-20^{\circ} \mathrm{C}$ until needed for

8 analysis. To process the samples, we placed the filter in a glass test tube along with 10

$9 \mathrm{ml} \mathrm{N}, \mathrm{N}$-dimethylformamide (DMF) to extract the chl $a$. The quantity of $\operatorname{chl} a$ was

10 determined using a spectrofluorophotometer (RF-5300 Shimadzu; Welschmeyer 1994).

12 Enumeration of microorganisms

13 To quantify the $C$. triciliatum cells and $M$. aeruginosa cells, we fixed $500 \mathrm{ml}$ water

14 samples with acidified Lugol's solution at a final concentration of $1 \%$, and concentrated

15 these samples using natural sedimentation. We counted the C. triciliatum cells in a

16 Fuchs-Rosenthal type haemacytometer and $M$. aeruginosa in Burker-Turk type

17 haemacytometer under a microscope at a magnification of $\times 400$ at least three times.

18 For enumeration of $M$. aeruginosa cell, concentrated samples were slightly sonicated at 
$155 \mathrm{kw}$ for $5 \mathrm{~min}$ to disperse Microcystis cells from colonies.

2 To quantify $M$. aeruginosa cells contained within the $C$. triciliatum food vacuoles, we

3 used samples fixed with acidified Lugol's solution and the method described above. A

$4 \quad 0.05 \mathrm{ml}$ aliquot of the concentrated sample was mounted on a glass slide, and at least 30

5 C. triciliatum cells were examined under a microscope at a magnification of $\times 400$. For

6 each sample, we averaged the numbers of $M$. aeruginosa cells ingested per flagellate.

\section{Digestion experiment}

9

We determined the digestion rate of $C$. triciliatum feeding on the $M$.

10 aeruginosa population using the methods of Dolan and Šimek (1998) and Nishibe et al.

11 (2002), with minor modifications. We isolated C. triciliatum from the surface water of

12 the experimental pond in August 2010, and maintained the clonal cultures in CT

13 medium (Watanabe and Ichimura 1997 or MCC-NIES;

14 www.nies.go.jp/biology/mcc/home j.htm), using M. aeruginosa NIES-843 as the food

15 source for $C$. triciliatum. The microorganism cultures were maintained in $300-500 \mathrm{ml}$

16 polycarbonate bottles at $25^{\circ} \mathrm{C}$ under a light intensity of $52 \mu \mathrm{Em}^{-2} \mathrm{~s}^{-1}$. We used $M$.

17 aeruginosa samples that were in the exponential growth phase and $C$. triciliatum

18 samples that were in the early stationary phase for the digestion and functional response 
1 experiments, respectively. A $6 \mathrm{ml}$ sample of the $C$. triciliatum culture was inoculated

2 into a $100 \mathrm{ml}$ polycarbonate bottle containing $12 \mathrm{ml} \mathrm{M}$. aeruginosa culture $\left(4.0 \times 10^{6}\right.$

3 cell $\mathrm{ml}^{-1}$ ). Following an incubation period of $12 \mathrm{~h}$ at $25^{\circ} \mathrm{C}$ in the dark, the flagellate

4 culture was diluted with $6 \mathrm{ml}$ of the mixture to $600 \mathrm{ml}$ fresh CT medium in triplicate in

$51 \mathrm{~L}$ Erlenmeyer flasks in the dark $\left(25^{\circ} \mathrm{C}\right)$ to halt ingestion. We removed $50 \mathrm{ml}$

6 subsamples from each flask at 30 min intervals for $150 \mathrm{~min}$, and fixed these subsamples

7 with acidified Lugol's solution at a final concentration $1 \%$. The fixed samples were

8 concentrated via natural sedimentation, and a $0.05 \mathrm{ml}$ aliquot of concentrated sample

9 was mounted on a glass slide. $M$. aeruginosa cells as well as those found in the food

10 vacuoles (ingested cells) were counted in 100 C. triciliatum cells under a microscope at

11 a magnification of $\times 400$.

We performed linear regression analyses and calculated the slope of the

13 regression of $\ln (\%$ initial average number of ingested $M$. aeruginosa per flagellate)

14 versus time to yield the digestion rate. Multiplying the slope by 100 gave a digestion

15 rate constant (\% cell content $\min ^{-1}$; Dolan and Šimek 1998; Nishibe et al. 2002).

As per Nishibe et al. (2002), we corrected the digestion rate at $25^{\circ} \mathrm{C}$ for the in

17 situ temperature in the experimental pond using $\mathrm{Q}_{10}=2.1$. The specific grazing rate of

18 C. triciliatum $\left(G_{\mathrm{c}}\right.$, M. aeruginosa cells flagellate $\left.\mathrm{e}^{-1} \mathrm{~h}^{-1}\right)$ was calculated by multiplying the 
1 corrected digestion rate by the average number of ingested $M$. aeruginosa cells per

2 flagellate for each sampling day, respectively. The clearance rate of C. triciliatum (nl

3 flagellate $\mathrm{h}^{-1}$ ) was calculated by dividing the flagellate grazing rate by the

4 corresponding $M$. aeruginosa cell density for each sampling day. The daily grazing

5 impact of $C$. triciliatum on the standing stock of $M$. aeruginosa $\left(G_{\mathrm{i}}, \%\right.$ standing stock

6 day $^{-1}$ ) was estimated as follows:

$7 \quad G_{\mathrm{i}}=100 \times\left(G_{\mathrm{c}} \times N_{\mathrm{c}} \times 24\right) / N_{\mathrm{m}}$,

8 where $N_{\mathrm{c}}\left(\right.$ cell $\left.\mathrm{ml}^{-1}\right)$ and $N_{\mathrm{m}}\left(\right.$ cells $\left.\mathrm{ml}^{-1}\right)$ are the cell densities of C. triciliatum and $M$.

9 aeruginosa for each sampling day, respectively (Dolan and Šimek 1998; Nishibe et al.

10 2002).

\section{Functional response experiment}

Before conducting the functional response experiment, we diluted the $C$.

14 triciliatum culture by adding $700 \mathrm{ml}$ of the mixture to $700 \mathrm{ml}$ fresh CT medium, and

15 incubated this culture in the dark for $12 \mathrm{~h}$ to obtain flagellates starved for food and

16 without residual growth, and to decrease $M$. aeruginosa abundance to a negligible level

$17\left(<1.0 \times 10^{3}\right.$ cells $\left.\mathrm{ml}^{-1}\right)$.

We fed the $C$. triciliatum (initial condition; $2.0 \times 10^{3}$ cells $\mathrm{ml}^{-1}$ ) on $M$. 
1 aeruginosa (initial condition; $1.0 \times 10^{4}$ to $2.1 \times 10^{6}$ cells $\mathrm{ml}^{-1}$ ) as prey, and examined the

2 resultant ingestion rate using the method of Jeong et al. (2005) with slight modifications.

3 We prepared various $M$. aeruginosa cell concentrations in the culture (initial condition;

$41.0 \times 10^{4}$ to $2.1 \times 10^{6}$ cells $\mathrm{ml}^{-1}$ ) in triplicate $300 \mathrm{ml}$ Erlenmeyer flasks, followed by

5 inoculation of $C$. triciliatum at a cell density of $2.0 \times 10^{3}$ cells $\mathrm{ml}^{-1}$. The cultures were

6 filled with CT medium to $100 \mathrm{ml}$, and were incubated in the dark at $25^{\circ} \mathrm{C}$. At $0,15,30$

7 and $45 \mathrm{~min}$ of incubation, a $10 \mathrm{ml}$ subsample was removed from each culture,

8 transferred to a $15 \mathrm{ml}$ tube, and then fixed with acidic Lugol's solution to a final

9 concentration of $1 \%$. We used a Burker-Turk haemacytometer to count $M$. aeruginosa

10 cells in the sample. A $0.05 \mathrm{ml}$ aliquot of sample was mounted on a glass slide and count

$11 M$. aeruginosa in the food vacuoles of $C$. triciliatum. To enumerate the $M$. aeruginosa

12 as prey, we inspected at least 30 flagellate cells, and produced a linear regression line

13 representing the relationship between the number of prey cells within a $C$. triciliatum

14 cell and the incubation time. We calculated ingestion rates (prey cells flagellate ${ }^{-1} \mathrm{~h}^{-1}$ )

15 according to the method of Sherr et al. (1987), and fitted all derived ingestion rates to a

16 Michaelis-Menten equation, as follows:

17

$$
I R=\frac{I_{\max }(x)}{K_{I R}+(x)},
$$

18 where $I_{\max }$ is the maximum ingestion rate (cells flagellate ${ }^{-1} \mathrm{~h}^{-1}$ ), and $K_{\mathrm{IR}}$ is the prey 
1 concentration sustaining one-half $I_{\max }$.

3 Results

\section{Monitoring Microcystis bloom and Collodictyon abundance}

$7 \quad$ chl $a$ concentrations were measured on days $28\left(155.3 \mu \mathrm{g} \mathrm{L}^{-1}\right)$ and $70\left(138.3 \mu \mathrm{g} \mathrm{L}^{-1}\right.$; Fig.

8 1B). That on day 70 roughly coincided with the initial $M$. aeruginosa bloom period (day

$984,10.8 \times 10^{4}$ cells $\mathrm{ml}^{-1}$; Fig. 1C). The abundance of C. triciliatum became relatively

10 high from days 22 to 35 , and from days 105 to 119 , with the highest abundance (291

11 cells $\mathrm{ml}^{-1}$ ) detected on day 28 (Fig. 1D). The number of M. aeruginosa cells ingested by

12 each flagellate cell was high on day 84 (10.8 cells flagellate $\left.{ }^{-1}\right)$, which fluctuated during

13 the study period (Fig. 1E).

The digestion experiment showed that the average number of $M$. aeruginosa cells ingested by each flagellate cell declined over time (Fig. 2), and we determined a

16 significant correlation between the $\ln (\%$ initial average numbers of ingested $M$.

17 aeruginosa per flagellate) and time $\left(r^{2}=0.909, p<0.01, \mathrm{n}=6\right)$. The digestion rate

18 constants of $C$. triciliatum feeding on $M$. aeruginosa was $0.73 \%$ cell contents $\min ^{-1}$, 
1 which was close to that determined in the previous study at $25^{\circ} \mathrm{C}(0.74 \pm 0.02 \%$ cell

2 contents $\min ^{-1}$, Nishibe et al. 2002).

The $C$. triciliatum grazing rates and clearance rates were 0.2-6.9 $M$.

4 aeruginosa cells flagellate ${ }^{-1} \mathrm{~h}^{-1}$ and 2.2 to $162.2 \mathrm{nl}$ flagellate ${ }^{-1} \mathrm{~h}^{-1}$, respectively (Table 1 ).

5 The daily grazing impact of $C$. triciliatum on $M$. aeruginosa was $0.0-25.3 \%$ of the $M$.

6 aeruginosa standing stock (Table 1$)$.

7

\section{Functional response}

The $C$. triciliatum population demonstrated a clear functional response to prey

10 density (Fig. 3). The half-saturation constant was $1.2 \times 10^{5}$ cells ml $^{-1}$, and the maximum

11 ingestion rate was 6.2 cells flagellate ${ }^{-1} \mathrm{~h}^{-1}$.

\section{Discussion}

14 In this study, we demonstrated the high potential of a protistan species to

15 reduce cyanobacterial blooms by herbivorous flagellate grazing. Our observations

16 included temperature-independent pattern changes in C. triciliatum abundance (Fig. 1D;

17 see Results section), in which $C$. triciliatum concentrations increased significantly on

18 two occasions (from days 22 to 35, and from days 105 to 119, Fig. 1D). Hence, it is 
1 likely that growth of $C$. triciliatum in the present study was independent of temperature.

3 (Fig. 1C), when the highest number of Microcystis cells was ingested by each $C$.

4 triciliatum cell (Fig. 1E). There was an abundance of Microcystis prey for C. triciliatum

5 predation during the period days 74 to 84 , suggesting a high possibility for remarkable

6 C. triciliatum growth. However, we did not record any noteworthy growth rates for the

7 flagellate during this period (Fig. 1D). One reason for this observation is the possible

8 presence of $C$. triciliatum predators, such as large rotifers and/or

9 carnivorous/omnivorous copepods. However, lacking any evidence of $C$. triciliatum

10 predation, we can only present this possibility as speculation and recommend it as a

11 topic for future study. C. triciliatum attained its highest concentration on study day 28

12 (Fig. 1D), when we also recorded the highest chl $a$ concentration (Fig. 1B). Previous

13 studies have reported that $C$. triciliatum is omnivorous (Mischke 1994; Nishibe et al.

14 2002). Thus, it seems likely that $C$. triciliatum could proliferate actively, with plenty of

15 food and in the absence of predators.

16 The highest number of Microcystis cells ingested by each $C$. triciliatum was

17 recorded on study day 84 (Fig. 1E). The abundance of $M$. aeruginosa decreased

18 significantly between days 84 and 91 (Fig. 1C). Using the specific ingestion rate of 84 
1 day and average $C$. triciliatum number between 84 and 91 days (Heinbokel 1978), we

2 estimated the $M$. aeruginosa loss to grazing by $C$. triciliatum between 84 and 91 days as

$31.8 \times 10^{4}$ cells $\mathrm{ml}^{-1}$. We calculated the decrease in Microcystis abundance during this

4 period as $8.6 \times 10^{4}$ cells $\mathrm{ml}^{-1}$, indicating that $21 \%$ of Microcystis abundance was

5 consumed by $C$. triciliatum grazing between 84 and 91 days. According to our

6 microscopic observations, the dominant food item of $C$. triciliatum during this period

7 was $M$. aeruginosa. Thus, the remarkable decrease in Microcystis abundance recorded

8 from days 84 to 91 was substantially due to $C$. triciliatum grazing. Grazing rates

9 calculated from digestion rates in the present were roughly consistent with those in our

10 previous study (Nishibe et al. 2002; Table 1). Nishibe et al. (2002) demonstrated that the

11 grazing impact of the flagellate may be of minor importance to the decline in $M$.

12 aeruginosa concentrations. However, in the present study, C. triciliatum grazing on

13 Microcystis was, if only temporarily, effective for decreasing cyanobacterial abundance.

14 The present study is thus the first to demonstrate the high potential of protistan grazing

15 on $M$. aeruginosa to reduce the cyanobacterial bloom.

16 We simply calculated the grazing impact using the data on cell densities of $C$.

17 triciliatum and M. aeruginosa, and in situ grazing rate of the flagellate. However, this

18 calculation may lead to an overestimation of grazing impact. Nishibe et al. (2002) 
1 reported that $C$. triciliatum might have preyed on small colonies ( $<50$ cells) of

2 Microcystis as well as unicellular ones. When Microcystis blooms attain to the

3 stationary phase and come to senescence, colony sizes of the cyanobacteria become

4 smaller (Ishikawa et al. 2004, Yamamoto \& Nakahara 2009). During the period between

584 days to 91 days, water temperature decreased, and chlorophyll $a$ concentration and

6 Microcystis cell density also did (Fig. 1A, B and C). These results indicate the

7 cyanobacterial senescence. So, it is likely that small colonies and/or unicellular

8 Microcysits were abundant during the period in the present study. Considering those, we

9 think our estimation of Collodictyon grazing impact on Microcystis abundance is valid,

10 though there still is the possibility of overestimation.

The maximum grazing rates and half-saturation constants recorded in the

12 present study (Table 2) are higher than those reported by Kim et al. (2006) and Wilken

13 et al. (2010). However, these previous studies utilized small flagellate species

14 (Diphylleia, ca. $25 \mu \mathrm{m}$ and Ochromonas, ca. $10 \mu \mathrm{m}$ ), whereas the $C$. triciliatum cells

15 used in the present study are comparatively large $(30-50 \mu \mathrm{m})$. Because the specific

16 ingestion rates of flagellates increase with increasing cell size (Jeong et al. 2005), the

17 results of the present study are comparable to those in the previous studies on a sliding

18 scale. Guo et al. (2008) reported that the flagellate genus Poterioochromonas has a 
1 higher half-saturation constant on $M$. aeruginosa prey, and the maximum ingestion rate

2 of the flagellate was lower than that of $C$. triciliatum (Table 2). The genus

3 Poterioochromonas is a mixotroph, and some mixotrophic algae are mainly

4 phototrophic with low phagotrophic ingestion rates (Guo et al. 2008). This may explain

5 the high half-saturation constant of Poterioochromonas.

6 It is interesting to note that the grazing rate estimated from the digestion rate

7 herein was close to that of the high food concentration measured in the functional

8 response experiment (Table 1 and Fig. 3), although these methods are different. The

9 possible reason for this similarity is that the $C$. triciliatum, in our digestion experiment,

10 were fed under a food-replete condition, likely similar to the high food concentration

11 used in our functional response experiment. The half-saturation constant of $C$.

12 triciliatum in the present study $\left(1.2 \times 10^{5} \mathrm{cell} \mathrm{ml}^{-1}\right)$ suggests that flagellate grazing on

13 Microcystis is initiated in the early stages of the bloom (Nishibe et al. 2004; Imai et al.

14 2009).

As determined in the present study, and similar to previous reports, $C$.

16 triciliatum cannot directly ingest a large colony of Microcystis (Nishibe et al. 2002).

17 There may be more effective grazers of M. aeruginosa than flagellates, including some

18 fish species (Miura 1990), cladoceran zooplankton (Hanazato and Yasuno 1984), 
1 rotifers (Snell 1980; Fulton and Pearl 1987; Jarvis et al. 1987), and amoebae

2 (Yamamoto and Suzuki 1984; Nishibe et al. 2004). In addition to grazing, other

3 Microcystis consumers may include the algicidal effects of heterotrophic bacteria

4 (Manage et al. 2000), and viruses (Yoshida et al. 2006). We have not yet collected data

5 on in situ loss of Microcystis concentrations due to biological processes, and such loss

6 may be synergistic with the aforementioned Microcystis eradicators. Additional studies

7 are needed to understand Microcystis loss due to biological processes.

9 Acknowledgments

10 This research was supported by the Environment Research and Technology

11 Development Fund (D-0905) of the Ministry of the Environment, Japan.

\section{Literature cited}

14 Baek SH, Hong SS, Song SY, Lee HO, Nakano S, Han MS (2009) Grazing effects on toxic and non-toxic Microcystis aeruginosa by the mixotrophic flagellate Ochromonas sp. J Freshwater Ecol 24:367-373

17 Burkert U, Hyenstrand P, Drakare S, Blomqvist P (2001) Effects of the mixotrophic flagellate Ochromonas sp. on colony formation in Microcystis aeruginosa. 
2 Carmichael WW (1992) Cyanobacterial secondary metabolites - the cyanotoxins. J Appl Microbiol 72:445-459

4 Cole GT, Wynne MJ (1974) Endocytosis of Microcystis aeruginosa by Ochromonas danica. J Phycol 10:397-410

6 Dokulil MT, Teubner K (2000) Cyanobacterial dominance in lakes. Hydrobiologia 438:1-12

8 Dolan JR, Šimek K (1998) Ingestion and digestion of an autotrophic picoplankter, Synechococcus, by a heterotrophic nanoflagellate, Bodo saltans. Limnor Oceanogr 43:1740-1746

11 Fulton RS, Pearl HW (1987) Toxic and inhibitory effects of the blue-green alga Microcystis aeruginosa on herbivorous zooplankton. J Plankton Res 9:837-855

13 Gobler CJ, Davis TW, Coyne KJ, Boyer GL (2007) Interactive influences of nutrient loading, zooplankton grazing, and microcystin synthetase gene expression on cyanobacterial bloom dynamics in a eutrophic New York lake. Harmful Algae 6:119-133

17 Guo S, Gan N, Zheng L, Song L (2008) Effect of Microcystis aeruginosa (Cyanobacteria) abundance on the growth and ingestion of Poterioochromonas 
sp. (Chrysophyceae). Bioinformatics and Biomedical Engineering, 2008. ICBBE 2008. The $2^{\text {nd }}$ International Conference on 16-18 May: 3639-3695

Hanazato Y, Yasuno M (1984) Growth, reproduction and assimilation of Moina macropoda fed on Microcystis and/or Chlorella. Jpn J Ecol (Otsu) 34:195-202

Heinbokel JF (1978) Studies on the functional role of Tintinnids in the Southern California Bight. II. Grazing rates of field populations. Mar Biol 47:191-197

Hodoki Y, Ohbayashi K, Kobayashi Y, Okuda N, Nakano S (2011) Temporal variation in cyanobacteria species composition and photosynthetic activity in experimentally induced blooms. J Plankton Res 33:1410-1416

Imai H, Chang KH, Kusaba M, Nakano S (2009) Temperature-dependent dominance of Microcystis (Cyanophyceae) species: M. aeruginosa and M. wesenbergii. J Plankton Res 31:171-178.

Ishikawa K, Walker RF, Tsujimura S, Nakahara H, Kumagai M (2004) Estimation of Microcystis colony size in developing water blooms via image analysis. J Jpn Soc Wat Environ 27:69-72 (in Japanese with English abstract)

Jarvis AC, Hart RC, Combrink S (1987) Zooplankton feeding on size fractionated Microcystis colonies and Chlorella in a hypertrophic lake (Hartbeespoort Dam, South Africa): implications to resource utilization and zooplankton succession. 
2 Jeong HJ, Park JY, Nho JH, Park MO, Ha JH, Seong KA, Jeng C, Seong CN, Lee KY, Yih WH (2005) Feeding by red-tide dinoflagellates on the cyanobacterium Synechococcus. Aquat Microb Ecol 41:131-143

5 Kim BR, Nakano S, Kim BH, Han MS (2006) Grazing and growth of the heterotrophic flagellate Diphylleia rotans on the cyanobacterium Microcystis aeruginosa. Aquat Microb Ecol 45:163-170

Latour D, Sabido O, Salencon MJ, Giraudet H (2004) Dynamics and metabolic activity of the benthic cyanobacterium Microcystis aeruginosa in the Grangent reservoir (France). J Plankton Res 26:719-726

11 Manage PM, Kawabata Z, Nakano S (2000) Algicidal effect of the bacterium Alcaligenes denitrificans on Microcystis spp. Aquat Microb Ecol 22:111-117

13 Mischke U (1994) Influence of food quality and quantity on ingestion and growth rates of three omnivorous heterotrophic flagellates. Mar Microbiol Food Webs 8: $125-143$

16 Miura T (1990) The effects of planktivorous fishes on the plankton community in a eutrophic lake. Hydrobiologia 200/201:567-579

18 Nishibe Y, Kawabata Z, Nakano S (2002) Grazing on Microcystis aeruginosa by the 

Microb Ecol 29:173-179

3 Nishibe Y, Manage PM, Kawabata Z, Nakano S (2004) Trophic coupling of a testate amoeba and Microcystis species in a hypertrophic pond. Limnology 5:71-76

5

6 26:2173-2176

18 Van Donk E, Cerbin S, Wilken S, Helmsing NR, Ptacnik R, Verschoor AM (2009) The 
effect of a mixotrophic chrysophyte on toxic and colony-forming cyanobacteria.

3 Watanabe MM, Ichimura T (1997) Freash- and salt-water forms of Spirulina platensis in axenic cultures. Bull. Jpn. Soc. Phycol 25 Suppl (Mem Iss Yamada) 371-377

5 Welschmeyer NA (1994) Fluorometric analysis of chlorophyll $a$ in the presence of chlorophyll $b$ and pheopigments. Limnol Oceanogr 39:1985-1992

7 Wilken S, Wiezer S, Huisman J, van Donk E (2010) Microcystins do not provide anti-herbivore defense against mixotrophic flagellates. Aquat Microb Ecol 59:207-216

Yamamoto Y, Nakahara H (2009) Seasonal variations in the morphology of bloom-forming cyanobacteria in a eutrophic pond. Limnology 10:185-193

Yamamoto Y, Suzuki K (1984) Light and electron microscope observations and prey specificities of an algophorous amoeba from Japanese freshwater. J Gen Appl Microbiol 30:411-417 and polysaccharide content of Microcystis aeruginosa (Cyanobacteria) during flagellate grazing. J Phycol 44:716-720

18 Yang Z, Kong F, Yang Z, Zhang M, Yu Y, Qian S (2009) Benefits and costs of the 
grazer-induced colony formation in Microcystis aeruginosa. Ann Limnol-Int $\mathbf{J}$

3 Yoshida T, Takashima Y, Tomaru Y, Shirai Y, Takao Y, Hiroishi S, Nagasaki K (2006) Isolation and characterization of a cyanophage infecting the toxic Cyanobacterium Microcystis aeruginosa. Appl Environ Microb 72:1239-1247

6 Zhang X, Watanabe MM, Inouye I (1996) Light and electron microscopy of grazing by Poterioochromonas malhamensis (Chrysophyceae) on a range of phytoplankton taxa. J Phycol 32:37-46

9 Zhang X, Hu HY, Men YJ, Yang J, Christoffersen K (2009) Feeding characteristics of a golden alga (Poterioochromonas sp.) grazing on toxic cyanobacterium Microcystis aeruginosa. Water Res 43:2953-2960 
1 Table 1. Grazing and clearance rates of Collodictyon triciliatum on Microcystis aeruginosa, and daily grazing impact of $C$. triciliatum

2 on the standing stock of $M$. aeruginosa in an experimental pond. Min: a minimum value, Max: a maximum value, SD: standard 3 deviation.

\begin{tabular}{lcc}
\hline & Range (Min - Max) & Means \pm SD \\
\hline $\begin{array}{l}\text { Grazing rate } \\
\left(M . \text { aeruginosa cells flagellate }{ }^{-1} \mathrm{~h}^{-1}\right)\end{array}$ & $0.2-6.9$ & $1.1 \pm 1.4$ \\
$\begin{array}{l}\text { Clearance rate } \\
\left(\mathrm{nl} \text { flagellate }{ }^{-1} \mathrm{~h}^{-1}\right)\end{array}$ & $2.2-162.2$ & $39.6 \pm 40.0$ \\
$\begin{array}{l}\text { Daily grazing impact } \\
\left(\% \text { standing stock day }{ }^{-1}\right)\end{array}$ & $0.0-25.3$ & $3.4 \pm 7.1$ \\
\hline
\end{tabular}


1 Table 2. Comparison of $I_{\max }$ and $K_{\mathrm{IR}}$ in different predators, when fed $M$. aeruginosa or Synechococcus. $I_{\max }$ : maximum ingestion rate, $K_{\mathrm{IR}}$ : the prey concentration 2 sustaining one-half $I_{\max }$.

\begin{tabular}{|c|c|c|c|c|}
\hline Protist & Prey & $I_{\max }$ & $K_{I R}$ & Source \\
\hline & & (cells flagellate ${ }^{-1} \mathrm{~h}^{-1}$ ) & $\left(10^{5}\right.$ cells $\left.\mathrm{ml}^{-1}\right)$ & \\
\hline Collodictyon triciliatum & M. aeruginosa NIES843 & 6.2 & 1.2 & Present study \\
\hline Diphylleia rotans & M. aeruginosa NIER -10001 & 0.56 & & Kim et al. (2006) \\
\hline Diphylleia rotans & M. aeruginosa NIES -298 & 0.73 & & Kim et al. (2006) \\
\hline Diphylleia rotans & M. aeruginosa NIES -101 (non-toxic strain) & 0.17 & & Kim et al. (2006) \\
\hline Diphylleia rotans & M. viridis NIES -102 & 0.35 & & Kim et al. (2006) \\
\hline Ochromonas sp. & M. aeruginosa PCC7806 wild type & $2.21 \pm 0.25$ & $0.13 \pm 0.25$ & Wilken et al. (2010) \\
\hline Ochromonas sp. & M. aeruginosa PCC7807 mutant & $1.68 \pm 0.14$ & $0.14 \pm 0.25$ & Wilken et al. (2010) \\
\hline Poterioochromonas sp. & M. aeruginosa FACHB 469 & 3.3 & 37.6 & Guo et al. (2008) \\
\hline
\end{tabular}


1 Fig 1. Changes in (A) Water temperature, (B) Chlorophyll $a$ concentration,

2 abundance of (C) M. aeruginosa and (D) C. triciliatum, and (E) average number

3 of ingested $M$. aeruginosa in the food vacuoles of $C$. triciliatum, in an

4 experimental pond. Error bars indicate standard deviations for each mean value in

$5(\mathrm{E})$.

6

7 Fig 2. Relationship between $M$. aeruginosa cell number in the food vacuoles of $C$.

8 triciliatum and time. Error bars indicate \pm standard error. Error bars that are not

$9 \quad$ visible are hidden behind the symbols.

10

11 Fig 3. Ingestion rate (cells flagellate ${ }^{-1} \mathrm{~h}^{-1}$ ) of C. triciliatum on M. aeruginosa as a

12 function of the initial prey concentration $\left(\right.$ cell $\mathrm{ml}^{-1}$ ). Each value was calculated

13 from a linear regression curve of the number of prey cells in flagellate vacuoles

14 over incubation time. The curve was fitted by a Michaelis-Menten equation (in

15 Materials and methods) using all treatments in the experiment. Ingestion rate (IR,

16 cell flagellate $\left.{ }^{-1} \mathrm{~h}^{-1}\right)=6.185[\mathrm{x} /(122280+\mathrm{x})], r^{2}=0.873, p<0.001$, where $\mathrm{x}$ is

17 Microcystis abundance. 

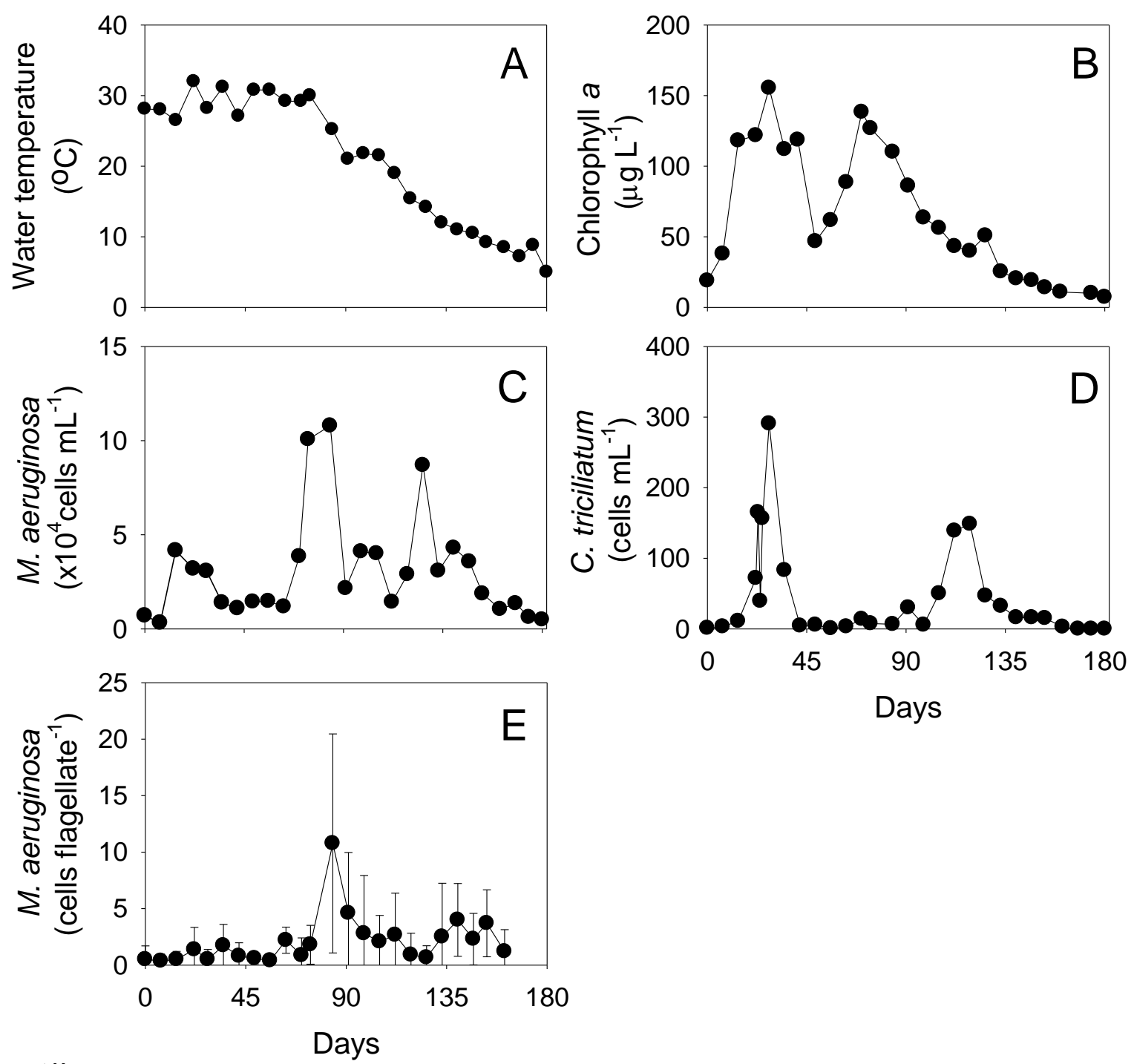

Fig. 1 Kobayashi et al.

27

28

29

30

31

32

33

34

35

36

37

38

39

40

41

42 


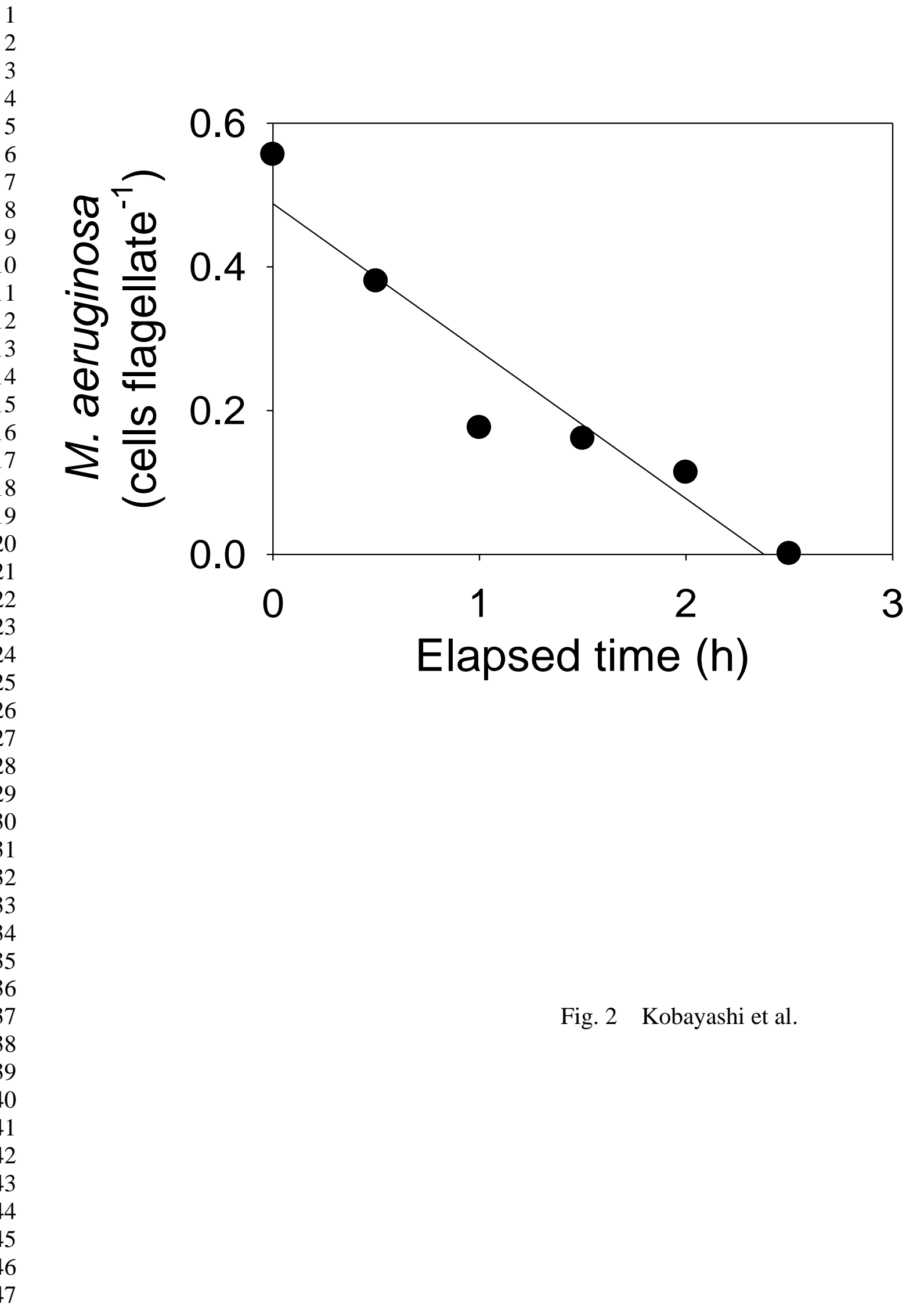


1

2

3

4

5

6

7

8

9

10

11

12

13

14

15

16

17

18

19

20

21

22

23

24

25

26

27

28

29

30

31

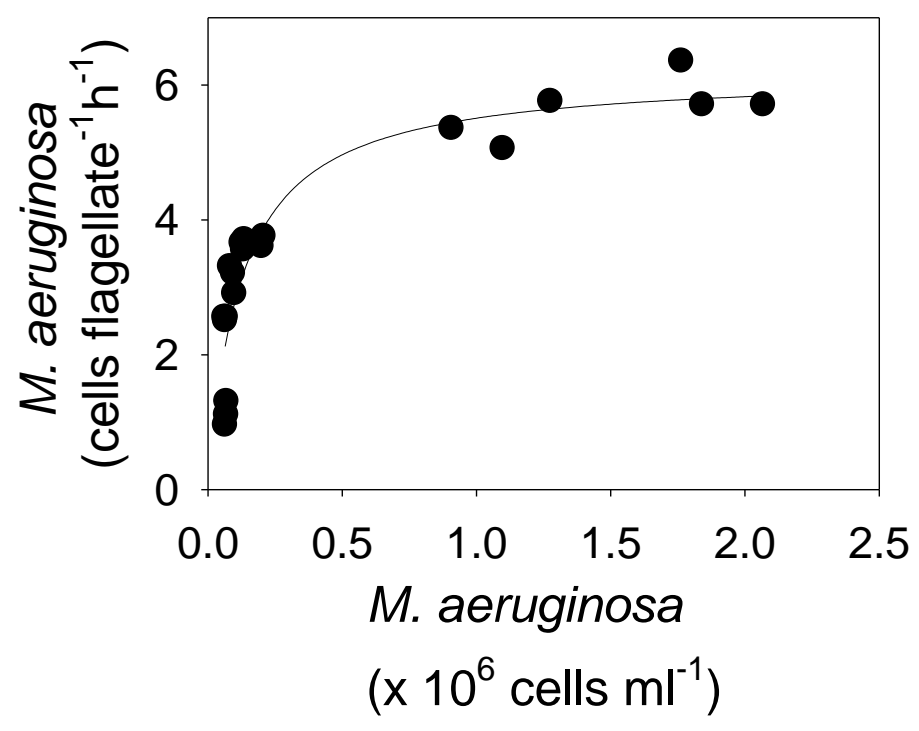

Fig. 3 Kobayashi et al. 